\title{
IMRT for Craniospinal Irradiation: A Dosimetric Comparison
}

\author{
M. Studenski \\ Thomas Jefferson University and Hospitals \\ T. Biswas \\ Thomas Jefferson University and Hospitals \\ Y. Xiao \\ Thomas Jefferson University and Hospitals
}

A. Harrison

Thomas Jefferson University and Hospitals

Follow this and additional works at: https://jdc.jefferson.edu/bodinejournal

Part of the Oncology Commons

Let us know how access to this document benefits you

\section{Recommended Citation}

Studenski, M.; Biswas, T.; Xiao, Y.; and Harrison, A. (2010) "IMRT for Craniospinal Irradiation: A Dosimetric Comparison," Bodine Journal: Vol. 3 : Iss. 1 , Article 17.

DOI: https://doi.org/10.29046/TBJ.003.1.016

Available at: https://jdc.jefferson.edu/bodinejournal/vol3/iss1/17

This Article is brought to you for free and open access by the Jefferson Digital Commons. The Jefferson Digital Commons is a service of Thomas Jefferson University's Center for Teaching and Learning (CTL). The Commons is a showcase for Jefferson books and journals, peer-reviewed scholarly publications, unique historical collections from the University archives, and teaching tools. The Jefferson Digital Commons allows researchers and interested readers anywhere in the world to learn about and keep up to date with Jefferson scholarship. This article has been accepted for inclusion in Bodine Journal by an authorized administrator of the Jefferson Digital Commons. For more information, please contact: JeffersonDigitalCommons@jefferson.edu. 


\section{IMRT for Craniospinal Irradiation: A Dosimetric Comparison}

Studenski, M., Biswas, T., Xiao, Y., Harrison, A.

Department of Radiation Oncology, Thomas Jefferson University and Hospitals, Philadelphia, PA

\section{Purpose}

This work tests the possibility of using IMRT to promote organ sparing for the treatment of CSI. The traditional CSI technique uses opposed lateral fields to treat the brain and posterior fields to treat the spine. Published manuscripts focusing on the possibility of IMRT for CSI have only looked at pediatric cases. Here, we will plan IMRT for CSI on adult patients to quantify the dosimetric gains when compared to traditional techniques.

\section{Method and Materials}

Four patients treated at our institution were chosen and a traditional $3 \mathrm{D}$ plan along with an IMRT plan was computed for each patient. The planned dose was $10 \mathrm{~Gy}$ and only the spine fields were optimized. The traditional plan used a cervical and thoracic spine field at 100 SSD while the IMRT plan split these two fields into five isocentric fields. OAR and target volumes receiving certain doses were calculated for each plan.

\section{Results}

IMRT resulted in greater target coverage, lower overall dose, and reduced OAR although the low dose was more spread out. The best target coverage was obtained on the single patient treated supine. For almost every OAR at each point, IMRT reduced the dose.

\section{Conclusion}

IMRT for CSI has a dosimetric advantage in both target coverage and OAR sparing over traditional beam arrangements. To further this study, we plan on repeating this process for six more patients and we also want to examine if there is a benefit to optimize the cranial fields in the IMRT plan along with the spine fields. Although it results in a more time consuming process, we have shown that there is evidence to pursue IMRT for adult CSI. 